\title{
CONTRIBUTION TO THE BRYOPHYTE FLORA OF THE VIEŠVILE் STATE STRICT NATURE RESERVE
}

\author{
Ilona Jukoniené ${ }^{1}$, Asta UselienĖ ${ }^{2}$, Vytautas Uselis ${ }^{3}$ \\ ${ }^{1}$ Nature Research Centre, Institute of Botany, Žaliujų Ežerų Str. 49, LT-08406 Vilnius, Lithuania; \\ ${ }^{2}$ Viešvilè State Strict Nature Reserve, Eičiai, LT-73141 Tauragès distr., Lithuania; \\ ${ }^{3}$ Nature Research Centre, Institute of Botany, Žaliujų Ežerų Str. 49, LT-08406 Vilnius, Lithuania; \\ * Corresponding author. E-mail: ilona.jukoniene@botanika.lt
}

\begin{abstract}
Jukonienė I., Uselienè A., Uselis V., 2013: Contribution to the bryophyte flora of the Viešvile State Strict Nature Reserve [Duomenų apie Viešvilès rezervato samanas papildymas] - Bot. Lith., 19(1): 75-79.

Based on the results of new investigations on the bryophyte flora of the Viešvile State Strict Nature Reserve, 28 moss and 12 hepatic species are reported as new to the bryophyte flora of the territory. Of these, 12 species are included into the Red Data Book of Lithuania. The scheme of distribution of the red-listed species in the reserve is presented.
\end{abstract}

Keywords: hepatics, mosses, conservation, important bryophyte area, Lithuania, Red Data Book.

Plant species diversity, proportion of common, rare and indicator species is a reflection of state and conservation value of protected territories and their habitats. The Viešvile State Strict Nature Reserve (SSNR), located in the western part of Lithuania, is one of the best bryologically investigated territories of the country. The first data on bryophyte diversity of the reserve appeared nearly 20 years ago (Naujalis et al., 1995; Grigaité \& Jukoniené, 1997; GrineviČIEnĖ \& Kalinauskaité, 1997). The latest list of bryophytes (JuKONIENE, 2003), which contained 208 species, proved the reserve to be important bryophyte area. Nevertheless, permanent investigations on the reserve vegetation and special investigations on bryophyte diversity during the last 10 years have supplemented the list with new species.

The present paper is based on collections made by A. Uselienè and I. Jukonienè mainly in 2004-2012 during special investigations on bryophytes and common studies on vegetation of the reserve. Voucher specimens of all species are deposited at the Herbarium of the Nature Research Centre, Institute of Botany (BILAS).
The names of the species follow Grolle \& LONG (2000) (hepatics) and HiLl et al. (2006) (mosses). To indicate species localities and their mapping, forest stand plans (2004) of the Viešvile SSNR were used.

\section{List of the species}

\section{Marchantiopsida}

Anastrophyllum hellerianum (Nees ex Lindenb.)

R.M.Schust. - On coniferous dead wood in swampy forests (compartments No 1, 22 and 27).

Barbilophozia attenuata (Mart.) Loeske - On coniferous dead wood in swampy forests and in spruce forests of the Viešvile River valley.

Calypogeia neesiana (C.Massal. et Carestia) Müll.Frib. - On dead wood and tree bases in swampy forests; quite frequent.

Fossombronia foveolata Lindb. - On bare peat in swampy black alder forest (compartment No 8).

Frullania tamarisci (L.) Dumort. - On Populus tremula, Alnus glutinosa, Tilia cordata and Fraxinus excelsior trunks in swampy forests (compartments No 1, 12, 18 and 23). 
Gymnocolea inflata (Huds.) Dumort. - In dry pine forest (compartment No 22).

Lejeunea cavifolia (Ehrh.) Lindb. - On Fraxinus excelsior trunk in black alder forest and on Populus tremula trunk in spruce forest (compartment No 13).

Lophozia ventricosa (Dicks.) Dumort. - On wet dead wood near Lake Glitis.

Odontochisma sphagni (Dicks.) Dumort. - On bare peat and on bases of pine trunks in the raised bogs Artoji and Lūšna.

Radula lindenbergiana Gottsche ex C.Hartm. On Populus tremula trunk in mixed forest (compartment No 61).

Riccardia multifida (L.) Gray. - In swampy spruce forest (compartment No 6) and in transitional mire (compartment No 1).

Riccardia palmata (Hedw.) Carruth. - In swampy forests (compartments No 1, 14 and 17).

\section{Bryopsida}

Hygroamblystegium varium (Hedw.) Mönk. - On bare ground of the banks of the Viešvile River.

Anomodon longifolius (Schleich. ex Brid.). Hartm. - On Fraxinus excelsior trunk in mixed forest (compartment No 17).

Bryum pallescens Schleich. ex Schwägr. - On bare ground in former homestead area (compartment No 21).

Calliergon richardsonii (Mitt.) Kindb. - In hollow of transitional mire near Lake Buveinis (compartment No 1).

Campyliadelphus chrysophyllus (Brid.) R.S. Chopra. - On dead wood near the Viešvile River (compartment No 22).

Campylophyllum sommerfeltii (Myrin) Hedenäs.On hummock in black alder forest (compartment No 17) and on dead wood near the Viešvile River (compartment No 26).

Dicranella subulata (Hedw.) Schimp. - On dead wood in coniferous forest and near the Viešvile River (compartment No 16).

Dicranum drummondii Müll. Hall. - In pine forest with Vaccinium vitis-idaea (compartment No 23).

Dicranum spurium Hedw. - In pine forests with Vaccinium vitis-idaea; quite frequent.

Dicranum viride (Sull. et Lesq.) Lindb. - On Alnus glutinosa trunk in swampy forest (compartment No 9).
Drepanocladus longifolius (Mitt.) Paris. - In swampy forests and on the banks of the Viešvile River.

Drepanocladus sendtneri (Schimp. ex H.Müll) Warnst. - In the hollow of transitional mire (compartment No 9).

Eurhynchiastrum pulchellum (Hedw.) Ignatov \& Huttunen. - In shady coniferous forests; quite frequent.

Hedwigia ciliata (Hedw.) P.Beauv. - On stones of former homestead and road embankment (compartments No 21, 22).

Kindbergia praelonga (Hedw.) Ochyra. - In spruce forests; quite frequent.

Meesia triquetra (L. ex Jolycl.) Ångstr. - In transitional mire (compartment No 11).

Orthotrichum affine Schrad ex Brid. - On trunks and branches of deciduous trees and large bushes.

Orthotrichum obtusifolium Brid. - On Populus tremula trunk in pine forest (compartment No 22).

Plagiothecium undulatum (Hedw.) Schimp. - In swampy spruce forests (compartments No 1, 6 and 16).

Pseudoscleropodium purum (Hedw.) M.Fleisch.In mesotrophic or eutrophic coniferous forests; quite frequent.

Racomitrium canescens (Hedw.) Brid. - In frontlet of dry pine forest (compartment No 1).

Rhizomnium pseudopunctatum (Bruch et Schimp.) T.J.Kop. - In swampy spruce forest (compartment No 1).

Rhytidiadelphus subpinatus (Lindb.) T.J.Kop. In wet mixed spruce and black alder forests; quite frequent.

Sciuro-hypnum reflexum (Starke) Ignatov \& Huttunen. - In spruce forests; frequent.

Sphagnum majus (Russow) C.O.E.Jensen. - In hollows of the raised bog Artoji.

Sphagnum papillosum Lindb. - In hollows of the raised bog Artoji.

Sphagnum quinquefarium (Braithw.) Warnst. On the slope of dune overgrown with pine forests of Vaccinium vitis-idaea (compartment No 5).

Sphagnum riparium Ångstr. - In quacking bog near Lake Glitis and in swampy forest (compartment No 5).

Sphagnum subsecundum Nees. - In transitional mire (compartment No 7) and fen (compartment No 21). 
Table 1. Distribution of the bryophyte species recorded as new to the Viešvilè State Strict Nature Reserve in various ecotopes and on various substrates

\begin{tabular}{|c|c|c|c|c|c|c|c|c|c|}
\hline \multirow{3}{*}{$\begin{array}{c}\text { Ecotopes and } \\
\text { substrates }\end{array}$} & \multicolumn{6}{|c|}{ Soil } & \multirow{3}{*}{$\begin{array}{l}\text { Tree } \\
\text { trunks }\end{array}$} & \multirow{3}{*}{$\begin{array}{l}\text { Dead } \\
\text { wood }\end{array}$} & \multirow{3}{*}{ Stones } \\
\hline & \multicolumn{2}{|c|}{ Mires } & \multicolumn{3}{|c|}{ Forests } & \multirow{2}{*}{$\begin{array}{l}\text { Open } \\
\text { sites }\end{array}$} & & & \\
\hline & $\begin{array}{c}\text { Raised } \\
\text { bogs }\end{array}$ & $\begin{array}{c}\text { Transi- } \\
\text { tional mires }\end{array}$ & $\begin{array}{l}\text { Spruce and } \\
\text { mixed }\end{array}$ & $\begin{array}{l}\text { Black } \\
\text { alder }\end{array}$ & Pine & & & & \\
\hline Number of species & 3 & 6 & 6 & 2 & 6 & 1 & 6 & 7 & 1 \\
\hline
\end{tabular}

Forty bryophyte species (12 hepatics and 28 mosses) were reported as new to the Viešvile SSNR. The species were recorded in various habitats and on various substrates (Table 1).

Most of newly recorded species are noteworthy. Targeted investigations on the hepatics of the reserve have significantly increased the number of epixyles and epiphytes. Among them are indicators (Riccardia palmata, Lophozia ventricosa) or specialists (Anastrophyllum hellerianum, Barbilophozia attenu$a t a$ ) of the Lithuanian Woodland Key Habitats (ANDERSSON et al., 2005). Twelve of the recorded species are included into the Red Data Book of Lithuania (Jukoniené, 2007): Calliergon richardsonii, Dicranum drummondii, D. viride and Frullania tamarisci ( $1^{\text {st }}$ category); Anastrophyllum hellerianum, Barbilophozia attenuata, Lejeunea cavifolia and Meesia triquetra ( $2^{\text {nd }}$ category); Dicranum spurium and Plagiothecium undulatum ( $3^{\text {rd }}$ category), Fossommbronia foveolata and Rhizomnium pseudopunctatum $\left(4^{\text {th }}\right.$ category); Dicranum viride is a species of European Habitat Directive, Annex 2. Former localities of the species were reported from the southwestern and eastern parts of Lithuania (JUKONIENĖ, 2007).

Data on the occurrence of some new species are important for the evaluation of their distribution in the country. The Viešvile SSNR is the second locality for the species Calliergon richardsonii, Dicranum drummondii, Fossombronia foveolata and Frullania tamarisci. In spruce forests of the reserve oceanic species Plagiothecium undulatum, earlier known from 3 localities in Western Lithuania, was recorded (JuKONIENEE, 2007). Contrarily, the localities of Dicranum spurium are the most western in the country; the species has been recorded from pine forests in the southern and eastern parts of Lithuania so far (JUKONIENE, 2007).

Liverwort Odontochisma sphagni and newly recorded Sphagnum species have not got a protected species status in Lithuania, but all they are known from solitary localities in Lithuania.
The localities of newly recorded red-listed species are distributed throughout the reserve (Fig. 1). Some of them, e.g. Dicranum spurium and Dicranum drummondii are found in the buffer zone of the territory as well. High concentration of the red-listed species is observed in the formerly indicated important bryophyte area - the surroundings of Lake Buveinis (compartment No 1) (JuKONIENE, 2003).

Thus, newly recorded bryophyte species in the Viešvilè SSNR prove again the territory to be important for the protection of bryophyte diversity (a total of 248 bryophyte species are registered in the territory). Numerous wetlands (raised bogs, transition mires, fens, springs, bog woodlands, black alder, birch and mixed swamp forests) that cover $60 \%$ of the reserve (RAščIUS, 1997) and old-growth forests (especially swamps) with limited anthropogenic impact provide suitable habitats for rare bryophyte species - 30 red-listed species are distributed in the territory.

\section{REFERENCES}

Andersson L., Kriukelis R., Skuja S., 2005: Woodland Key Habitat Inventory in Lithuania. Lithuanian Forest Inventory and Management Institute, Kaunas \& Regional Forestry Board of Östra Götaland, Linköping, Sweden. - Vilnius.

JuKONIENĖ I., 2003: Viešvilès valstybinio rezervato samanų flora. - Botanica Lithuanica, Suppl. 5: $25-46$.

JukonienĖ I., 2007. Bryophytes. - In: RAšOMAVIČIUS V. (ed.), Lietuvos raudonoji knyga: 262-354. - Vilnius.

Grigaitė O., JukonienĖ I., 1997: Lapuotosios samanos (Bryopsida). - In: LAPELĖ M., Ivinskis P., Juškaitis R., Paltanavičıus S. (eds), Lietuvos valstybiniu rezervatų flora ir fauna: 34-38. - Vilnius. 


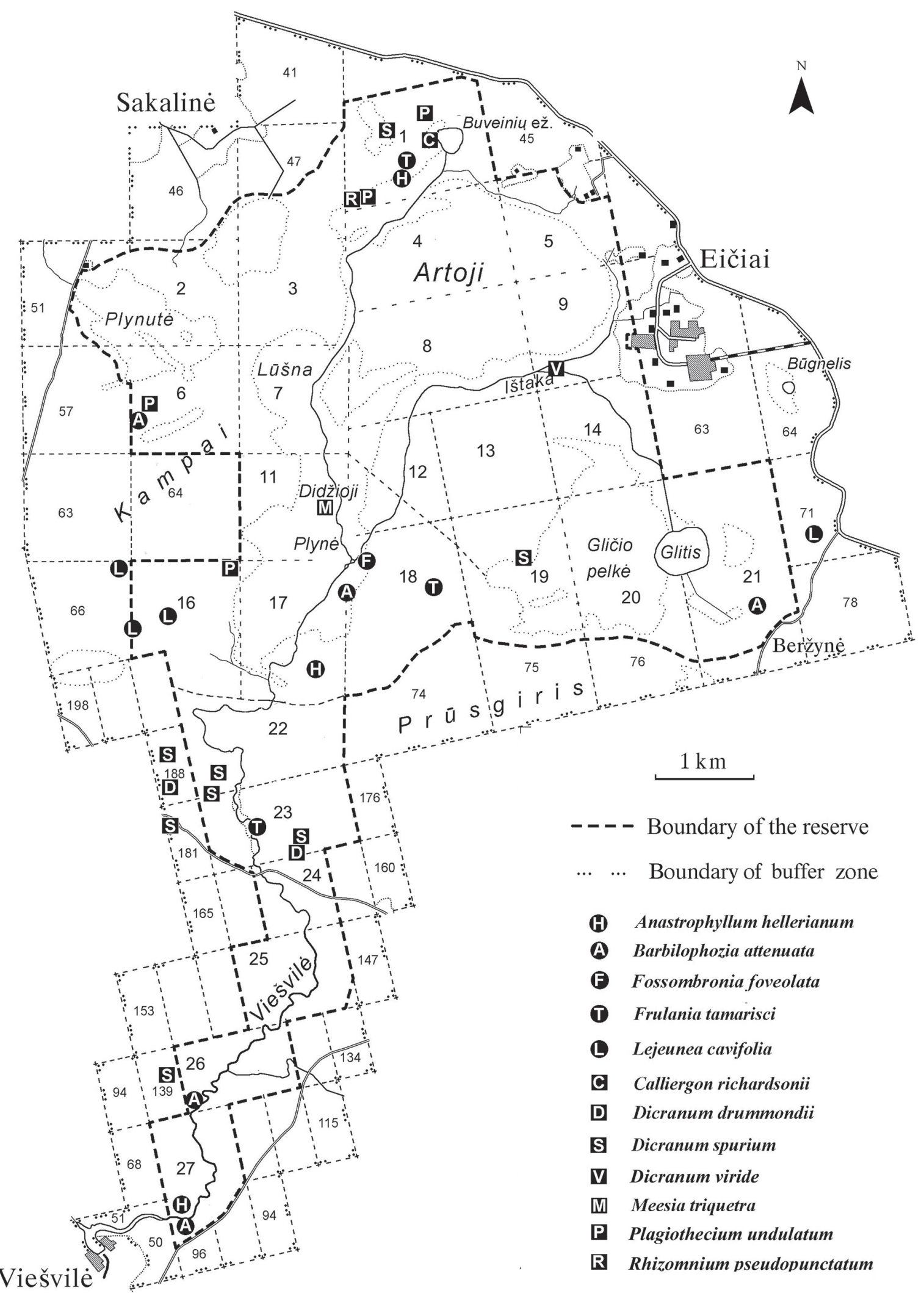

Fig. 1. Scheme of the distribution of newly recorded protected bryophyte species in the Viešvilè State Strict Nature Reserve 
GrinevičIIENĖ M., Kalinauskaité N., 1997: Kerpsamanès (Hepaticopsida). - In: LAPELĖ M., Ivinskis P., JušKaitis R., PaltanavičIus S. (eds), Lietuvos valstybinių rezervatų flora ir fauna: 39 41. - Vilnius.

Grolle R., Long D.G., 2000: An annotated checklist of the Hepaticae and Anthocerotae of Europe and Macaronesia. - Journal of Bryology, 22: 103-140.

Hill M.O., Bell N., Bruggeman-Nannenga M.A., Brugués M., Cano M.J., Enroth J., Flatberg K.I., Frahm J.-P., Gallego M.T., Garilleti R., Guer- ra J., Hedenäs L., Holyoak D.T., Hyvönen J., Ignatov M.S., Lara F., MazimpaKa V., Munoz J., SöDERSTRÖM L., 2006: An annotated checklist of the mosses of Europe and Macaronesia. - Journal of Bryology, 28: 198-267.

Naujalis J., KalinausKaitė N., GrineviČIENĖ M., 1995: Vadovas Lietuvos kerpsamanėms pažinti. - Vilnius. RAšČIUS G., 1997: Rezervatų charakteristika. - In: Lapelė M., Ivinskis P., JušKaitis R., Paltanavičius S. (eds), Lietuvos valstybinių rezervatų flora ir fauna: 6-8. - Vilnius.

\section{DUOMENŲ APIE VIEŠVILĖS REZERVATO SAMANAS PAPILDYMAS}

\section{Ilona JukonienĖ, Asta UselienĖ, Vytautas Uselis}

\section{Santrauka}

Straipsnyje pateikiami nauji duomenys apie Viešvilès rezervato samanas. Atlikus rezervato kerpsamanių floros tyrimus, patikrinus anksčiau surinktą rezervato samanu kolekciją, rezervato samanų sąrašas pasipilde 40 samanu rūšių (12 kerpsamanių ir 28 lapsamanių). Dvylika iš šių rūšiu irašytos i Lietuvos raudonają knygą. Retų rūšiu gausiau nei kitur aptinkama anksčiau išskirtoje samanoms svarbioje teritorijoje - Buveinių apyežeryje. 